\title{
Oral peptide and protein delivery: Intestinal obstacles to delivery and commercial prospects
}

\begin{abstract}
Introduction: Pharmaceutical research and development is increasingly focussed on biologicals including peptide and protein drugs. Despite their growing importance and almost 100 years of research the vast majority are still only available by injection. Oral bioavailabilities of peptide and protein drugs are very low mainly because of the stability and permeability barriers of the gastrointestinal tract.
\end{abstract}

Areas Covered: Data from studies of peptide/protein drug oral bioavailability, stability and permeability in the stomach, small intestine and large intestine has been compiled to make comparisons between the various regions of the gastrointestinal tract and peptides and proteins with differing characteristics. Assessment of the oral formulation strategies which have progressed farthest in clinical trials has been conducted to identify which have the best potential for future success.

Expert Opinion: The oral delivery of peptides and small proteins is becoming increasingly likely by utilising formulations which combat the stability challenges of the gastrointestinal tract and disrupt the intestinal cell membranes to enable absorption. However oral bioavailabilities remain low and therefore high, potentially toxic and expensive doses of the peptide/protein drugs are needed to elicit a therapeutic effect. There is very little research into larger proteins making their oral delivery unlikely in the near future.

\section{Keywords}

Gastrointestinal stability, oral peptide/protein bioavailability, oral peptide/protein delivery 


\subsection{Introduction}

Numerous peptide and protein drugs are available for a wide variety of therapeutic

applications Productivity in research and development by large pharmaceutical companies has declined and with it focus has shifted from small molecule therapeutics to biologicals such as peptides and proteins ${ }^{1}$. Patent applications by leading pharmaceutical companies for biologicals now exceeds that of small molecules and this gap is widening. Reflecting this the top selling pharmaceutical drugs of 2012 were protein drugs, more specifically antibodies; adalimumab (Humira ${ }^{\circledR}$, Abbvie) and infliximab (Remicade ${ }^{\circledR}$, Johnson \& Johnson, Merck \& Co. $)^{2}$. Of the top ten selling drugs seven were protein drugs. This shift away from smaller molecules towards larger biologicals presents new challenges to formulators.

Peptide therapeutics is a dynamic and growing part of the pharmaceutical industry with more than 100 peptide and protein therapeutics currently marketed worldwide, approximately 270 peptides in clinical testing and over 400 in pre-clinical development ${ }^{3,4}$. Biotechnological advances have enabled their production on a commercial scale and the therapeutic peptide market is predicted to grow from $€ 5.3$ billion in 2003 to $€ 11.5$ billion in $2013^{3}$. However this represents less than $2 \%$ of the global pharmaceutical market, estimated to reach $€ 770$ billion in 2013.

Despite the importance and growth of the peptide and protein therapeutic area, very few are available orally. The vast majority are only available by injection despite oral preparations being the most desirous dosage form from both the patient and pharmaceutical manufacturer's view. The gastrointestinal (GI) tract contains numerous obstacles to oral drug delivery and high inter and intra subject variability makes oral delivery of even small molecules challenging ${ }^{5}$. These obstacles are multiplied for peptide and protein therapeutics as they are natural substrates for gastrointestinal degradation. 
Among the few orally available peptide and protein drugs are pancreatin, vancomycin, octreotide, desmopressin and linaclotide. Oral delivery for these drugs is possible due to their unique characteristics or their delivery requirements. Pancreatin, vancomycin and linaclotide are orally delivered as their site of therapeutic action is in the GI tract. Pancreatin is delivered to the small intestine to replace a lack of pancreatic enzymes and vancomycin is delivered to the colon to treat Clostridium difficile infection. Pancreatin is generally enterically coated to protect the enzymes from denaturation in the stomach. The glycosylated, tricyclic structure of vancomycin may offer protection from enzymatic digestion. Linaclotide is used to treat irritable bowel syndrome and binds a receptor locally in the intestinal epithelium ${ }^{6}$. Its spiral structure fixed by three disulphide bonds may aid its intestinal stability.

Desmopressin and cyclosporine A are absorbed from the GI tract into the systemic circulation. Cyclosporine A possess' some unique characteristics amongst peptides that make it suitable for oral delivery. It has an oral bioavailability of approximately $30 \%$, much greater than for most peptide and protein drugs. Unlike most peptides and proteins it is highly lipophilic $(\log \mathrm{P} 3)$ which may enable its partition across the lipid membranes of intestinal cells. Its bioavailability is actually limited by this high lipid solubility as its aqueous solubility is low. Formulations of cyclosporine A are pre-concentrates of oil and surfactant that upon contact with GI fluid form emulsions or microemulsions. Cyclosporine A also has a cyclic structure which may provide protection from digestive enzymes.

Desmopressin does not possess the lipophilicity of cyclosporine $\mathrm{A}, \log \mathrm{P}-1.95^{7}$, and is only part cyclised so may have less enzymatic protection, yet it is orally delivered. Its oral bioavailability is less than $1 \%$ but as only a very low dose is required to elicit its therapeutic effect only a very low oral bioavailability is required. Its wide therapeutic window also minimises any problems encountered by variations in oral absorption. 
Currently the vast majority of peptide and protein drugs are not delivered orally due to their low oral bioavailability. Table 1 lists the bioavailabilities of peptide and protein drugs when administered orally or directly to various intestinal segments of humans and animals. With the exception of cyclosporine A, due to the reasons discussed above, all of the peptides and proteins listed have bioavailabilities of less than $5 \%$ in conscious animals, relative to intravenous or subcutaneous delivery, regardless of their size and location of administration. The low bioavailabilities displayed in table 1 reveal that even if peptide/protein delivery is targeted to a specific part of the GI tract it will still experience huge obstacles to its stability and absorption. Bioavailabilities were slightly higher when drugs were administered to the jejunum compared to the other segments, however the results were gathered from many different studies which may have used different parameters making comparisons difficult. Most of the studies weren't conducted in humans so may not be representative of the oral fate of peptide and protein drugs in humans.

This review aims to more closely identify the barriers to oral peptide/protein delivery which must be overcome by formulators. This may enable reduction of the costs and complexity of the proposed delivery strategies. Identification of trends in structure and size with bioavailability may allow research to focus on those drugs and oral delivery strategies with the best potential for success. The formulations which are showing the most potential in human clinical trials have also been assessed to determine which strategies are most likely to make universal oral peptide and protein drug delivery possible.

\subsection{Stability}

\subsection{Gastric instability}


The first major barrier faced by an orally delivered peptide or protein drug is the stomach. The stability of peptide and protein drugs has been assessed using simulated gastric fluid either with or without pepsin and in animal or human gastric fluids as shown in table 2.

The stomach contains two major threats to stability; acid and pepsin. Gastric $\mathrm{pH}$ may alter the ionisation of amino acids affecting the bonds that hold together the secondary and tertiary structure of larger peptides and proteins causing a loss of specific structure and function. Pepsin cleaves peptide bonds within a peptide chain (endopeptidase) between hydrophobic, preferably aromatic amino acids.

Table 2 indicates gastric stability of peptides and proteins is at least partly dependent on their size. The smaller peptides have high stability in gastric fluids and mucosa. This may be due to their lack of higher structure which could be disrupted by acid and lack of specific pepsin cleavage motifs. The disulphide bridges of oxytocin, vasopressin and linaclotide may also provide protection from pepisn. However mid-sized peptides such as vasoactive intestinal peptide were degraded by pepsin but their relatively simple structure remained stable in acid alone $^{8}$. The larger peptides and proteins appear to be susceptible to gastric denaturation and would need enteric protection for oral delivery. However for smaller peptides not susceptible to acid denaturation and pepsin digestion gastric protection may not be necessary.

\subsection{Small intestinal instability}

The small intestine is the major site of peptide and protein digestion and therefore represents a barrier to oral peptide and protein drug delivery. The small intestine contains luminally secreted proteases and membrane bound peptidases. Peptides and proteins with cysteine residues may also be degraded by thiol-disulfide exchange reactions by reduced glutathione. Glutathione is part of the antioxidant defence system of the GI tract 
The peptides tested in small intestinal fluids displayed a similar size dependent stability as that seen in the gastric fluids, table 3. Stability decreased with increasing size, possibly due to the presence of more enzyme cleavage sites. However unlike the gastric fluids only the very smallest peptides were completely stable in the small intestinal fluids. This may be due to the presence of more than one protease in the small intestinal fluids. The proteins tested in the simulated small intestinal fluids actually showed greater stability than the large peptides. This may be because proteins do not have as easily accessible peptide bonds as their peptide chains are involved in complex secondary and tertiary structures. However, if orally delivered these structures may be unfolded in the stomach and so would be vulnerable to enzymatic digestion. These results show that formulation protection from small intestinal proteases is essential for successful oral delivery of all but the smallest peptides.

Degradation of peptides was generally reduced in the intestinal mucosal homogenates ${ }^{9}$ and proteolytic activity was found to be lower here compared to the lumen ${ }^{10}$. Formulations which target peptide/protein drug release upon attachment to the intestinal mucosa may increase the likelihood of successful oral delivery.

Different regions of the intestinal tract have been shown to have differing proteolytic activities. Jejunal extracts from rats and brushtail possums were found to have greater proteolytic activity than those from the ileum ${ }^{10,11}$. LHRH was most degraded in brushtail possum jejunal extracts than in those from the ileum or duodenum ${ }^{12,13}$ and linaclotide showed similar stability in rat intestinal fluids ${ }^{6}$. These results suggest formulations targeted to release their peptide/protein drug in the distal small intestine may have an increased chance of systemic absorption.

\subsection{Large intestinal instability}


Large intestinal degradation of peptides and proteins can result from their fermentation by colonic microbes or digestion by proteases secreted by these microbes. Proteolytic activity in the large intestinal fluids and mucosa has been found to be lower than in the small intestine of brushtail possums ${ }^{10}$ and rats ${ }^{11}$. Degradation of LHRH $^{12,13}$, glatiramer acetate ${ }^{14}$ and desmopressin ${ }^{15}$ was lower in colonic fluids and mucosa compared to small intestinal fluids and mucosa. These results indicate the large intestine may be a more attractive target for oral peptide and protein drug delivery than the small intestine.

Table 4 shows despite reduced proteolytic activity degradation of peptides and proteins still occurred in large intestinal fluids and mucosa but in general degradation here doesn't appear to be as complete as in the gastric and small intestinal fluids. There also doesn't appear to be the relationship between size and stability as seen in the other gastrointestinal fluids. This may be because degradation by microbial fermentation is not correlated to size whereas enzymatic digestion appears to increase with increasing size. However there is limited data available for peptide/protein drug stability in large intestinal fluids so it is harder to draw reliable conclusions.

\subsection{Permeability}

The routes for peptide/protein drug absorption from the intestinal lumen into the systemic circulation are between cells, paracellular, through cells, transcellular, by endocytosis/pinocytosis or by carrier mediated transport.

The very low oral bioavailabilities of peptide and protein drugs are not just the result of their instability but also poor permeability. Human colon carcinoma (Caco-2) cells are widely used as a model of intestinal epithelium for studying transepithelial drug transport. In Caco-2 cell absorption studies there was no uptake of erythropoietin and granulocyte colony stimulating factor (GCSF) ${ }^{16}$ negligible salmon calcitonin transport ${ }^{17}$ and even with the very 
small peptide thyrotropin releasing hormone (TRH) more than $90 \%$ of the drug remained on the donor side ${ }^{18}$. Absorption by Caco-2 cells may however underestimate in vivo absorption as they resemble colonic more than small intestinal tissue and have tighter junctions. This may explain poor correlations seen between the absorption of peptides in Caco- 2 cells and rat intestinal cells ${ }^{19}$.

Permeability has been found to be size dependent and decreases rapidly when molecular weight is greater than $700 \mathrm{Da}^{20-22}$. As even the smaller peptides are larger than $700 \mathrm{Da}$ their intestinal absorption is likely to be very limited. The paracellular route may be more compatible with hydrophilic peptides and proteins but is particularly limited by the tight junctions between cells and restricted to molecules less than $200 \mathrm{Da}^{20-22}$. The paracellular spaces also contribute less than $1 \%$ of the total mucosal surface ${ }^{23}$.

Most peptide and protein drugs are hydrophilic and therefore not compatible with passive transcellular absorption. The lipophilic nature of cyclosporine A is thought to account for its higher oral bioavailability. However poor correlations between the lipophilicity of peptides and their uptake across the Caco-2 in vitro intestinal cell model ${ }^{24}$ and rat ileum ${ }^{25}$ have been observed. Instead both studies found the more hydrogen bonds a peptide could form with water the less permeable it was, possibly due to the greater amount of energy required to break these bonds before absorption. Methylation of model peptides increased Caco-2 cell permeability of model peptides by reducing hydrogen bonding potential ${ }^{24}$. Conformational flexibility and molecular radii have therefore been shown to be at least as crucial as lipophilicity for absorption.

These studies show that the best candidates for oral delivery are small peptides with high flexibility and low H-bonding potential. Modifying proteins and peptides by reducing $\mathrm{H}$ bonding potential may be a good option for increasing oral peptide/protein drug 
bioavailability but any modifications should not impair the therapeutic efficacy of the drug. Many potential delivery strategies have employed components to open the paracellular channels or disrupt the cell membranes to increase permeation. However these risk the absorption of not just the drug but potentially toxic entities.

The most permeable segment of the gastrointestinal tract is the small intestine due to its large absorptive surface area and leakier paracellular channels than those found in the large intestine or stomach. Absorption of the following peptides was greater from the small intestine than the stomach or large intestine when administered to GI tract segments in rats and dogs: vasopressin ${ }^{26}$, calcitonin ${ }^{11,27-29}$, azetirelin ${ }^{30}$ and desmopressin in humans ${ }^{31}$. These results indicate that for successful oral delivery peptide and protein drugs should be targeted to the small intestine for absorption.

Studies which compared the absorption of peptide and protein drugs from small intestinal segments in rats, beagle dogs and rabbits found that calcitonin ${ }^{11,27,28}$, insulin ${ }^{32}$, oxytocin, carbetocin ${ }^{33}$, desmopressin, vasopressin ${ }^{33,34}$, azetirelin ${ }^{30}$ and leuprolide ${ }^{35}$ showed greater absorption from the distal than proximal small intestine. This may be due to lower proteolytic activity in the ileum than the jejunum. The $\mathrm{M}$ cells of gut associated lymphoid tissue are known to sample macromolecules from the ileum and may be able to increase peptide/protein absorption from this segment. In human studies, however, desmopressin ${ }^{31}$ and octreotide ${ }^{36}$ absorption was greater from the proximal small intestine than the ileum. This disparity with animal absorption studies could be due to their higher percentage of $\mathrm{M}$ cells in Peyer's patches, $10-50 \%$, in rodents, and $46 \%$ in rabbits ${ }^{37}$ compared to $5 \%$ in humans.

\subsection{Oral delivery strategies}


To overcome the stability and permeability barriers to oral peptide and protein delivery many different strategies have been attempted and are listed in figure 1. They have been reviewed extensively elsewhere ${ }^{38-41}$. Strategies to overcome the gastric barrier include enteric carriers and coatings to protect the peptide/protein drug or delivery with excipients to raise the gastric $\mathrm{pH}$. To overcome the enzymatic obstacles of the small intestine formulations with protease inhibitors and excipients which lower the $\mathrm{pH}$ have been developed. Colonic targeted dosage forms have also been formulated to circumvent the more degradative conditions of the stomach and small intestine. To increase intestinal permeation excipients which can open paracellular channels, disrupt the intestinal membrane and increase mucoadhesion have been utilised. The peptides and proteins to be delivered have also been modified by lipidisation or conjugation to targeting ligands to increase absorption. Incorporation into polymeric and lipid nano/microparticles, micelles, liposomes and emulsions has also been investigated. These can provide protection to the encapsulated peptides and proteins and increase permeation. While these strategies have academic interest very few have reached human clinical trials.

The vast majority of oral delivery research has been conducted with calcitonin and insulin, possibly due to the frequency of their administration and clinical importance. Some research has also focused on improving the oral delivery of cyclosporine A, desmopressin and pancreatin. There has also been research conducted with the peptide hormones leuprolide, oxytocin and octreotide possibly due to their smaller size making them more compatible for oral delivery. There has been very little investigation into the oral delivery of larger proteins. This could be because of the inherent difficulties of maintaining their complex structure during GI transit and the greater difficulty of absorption of such large molecules. Recently the oral delivery of glucagon like peptide-1 (GLP-1) and its analogues exenatide and 
liraglutide has been explored possibly due to their importance in the treatment of type 2 diabetes.

\subsection{Commercial oral delivery strategies}

In addition to academic research and development many biotechnology companies have also been pursuing oral peptide and protein formulations. This has met with mixed success. Unfortunately many strategies which demonstrated promising results in preclinical or early stage clinical trials have been discontinued meaning their full potential has not been fully realised.

\subsubsection{Discontinued/inactive oral delivery strategies}

AutoImmune with Eli Lilly and Provalis with Cortecs Ltd developed oral insulin formulations which showed efficacy in phase II clinical trials but they have since been suspended. Oral insulin delivery strategies developed by Endorex, based on liposomes, by Apollo Lifesciences, based on vitamin B12 coated nanoparticles, and by Bow pharmaceuticals, based on encapsulation in a dextran matrix, have also been suspended. Diasome developed a nanosized oral insulin that was stable at low $\mathrm{pH}$ and in the bloodstream. This was tested in phase II and III clinical trials with type II diabetics in 2009 but there have been no further trials or information regarding this product.

Oral formulations of insulin, developed by Diabetology, and calcitonin, by Bone Limited, demonstrated efficacy in Phase I and IIa clinical trials using Axcess ${ }^{\mathrm{TM}}$ delivery technology. This delivery technology involves encapsulation in enteric coated capsules with an absorption enhancer and bile acids. These trials were conducted in 2004 and 2005, there have been no further trials but Diabetology recently announced a partnership with USV Limited to develop oral insulin for the Indian market. 
Unigene completed a phase II clinical trial with their oral parathyroid hormone formulation in November 2011 successfully meeting endpoints. The formulation included digestion inhibitors and absorption enhancers and increased oral bioavailability from $<1 \%$ to $20 \%$. However this project has now been suspended.

\subsubsection{Current oral delivery strategies in clinical trials}

Despite the suspension of many projects some have completed successful clinical trials and are pursuing filings in the near future. These active programs are outlined in table 5.

Emisphere's Eligen ${ }^{\circledR}$ technology utilises delivery agents, which interact non-covalently with peptide and protein drugs exposing their hydrophobic side chains, increasing their lipophilicity and absorption. This strategy was one of the most promising for peptide/protein delivery increasing the oral bioavailabilities of parathyroid hormone ${ }^{42}$, human growth hormone ${ }^{43}$, salmon calcitonin ${ }^{44}$ and interferon- $\alpha^{43}$ in rats and primates. However, a three year phase III clinical trial with salmon calcitonin, which ended in 2011, failed to meet primary and secondary endpoints in treating postmenopausal osteoporosis and its planned 2012 submission has been abandoned. Its oral programs for parathyroid hormone, human growth hormone and insulin for type I diabetes have all been terminated. Its remaining oral delivery program is with GLP-1 analogs and insulin for type 2 diabetes which entered phase I clinical trials in 2010 .

Biocon have continued the development of an oral insulin formulation, IN-105, initiated originally by the Nobex Corporation. Phase III clinical trials did not meet desired expectations, but this was not thought to be due to a lack of efficacy necessarily but due to behavioural modifications of those taking the placebo. The project is still active though and a partnership with Bristol-Myers-Squibb for further development appears likely. 
The other oral peptide/protein delivery system that has completed phase III clinical trials is Tarsa Therapeutic's OSTORA ${ }^{\mathrm{TM}}$, salmon calcitonin tablet. It successfully met all clinical endpoints and represents the most promising oral peptide strategy for future availability ${ }^{45}$. However an FDA Advisory Committee decided in 2013 that salmon calcitonin should no longer be broadly marketed as the risk of it causing cancer outweighs its benefits. This unfortunately may end the progress of this oral peptide which had progressed much farther than many others.

Chiasma's oral octreotide is currently undergoing phase III clinical trials and they are hopeful of filing a new drug application (NDA) in the near future. A new partnership with Roche was announced in February 2013 to develop and commercialise Octreolin ${ }^{\mathrm{TM}}$. Amarillo Bioscience's oral formulation of interferon $\alpha$ and Oramed's oral insulin and exenatide have entered or completed phase II clinical trials and it remains to be seen if they can progress to further clinical trials.

The programs all involve peptides/proteins of less than $6 \mathrm{kDa}$, except for interferon $\alpha$ which is targeted to throat receptors and so doesn't have to overcome the stability and permeability issues of oral systemic delivery. The oral delivery of larger proteins to the systemic circulation does not look like becoming a reality soon. However the success of Tarsa Therapeutic's phase III clinical trial with calcitonin suggests it may not be long before relatively large, hydrophilic peptides can be administered orally.

The formulations developed by Tarsa, Chiasma and Oramed all comprise protective and permeation enhancing elements. The dosage forms developed by Tarsa and Oramed are enteric coated, have protease inhibitors and permeation enhancers which can disrupt the intestinal membrane. Chiasma's formulation involves delivery in a protective hydrophobic medium with permeation enhancers. These strategies have the best potential for future 
success and indicate that formulations need to provide protection from acid and enzymes and permeation enhancement.

Emerging oral peptide/protein drug delivery strategies in preclinical or entering clinical trials seem mainly to be based on modified nanoparticles. Access Pharmaceuticals have formulated peptide and protein drugs in nanoparticles coupled to cobalamin, a vitamin B12 analog. NOD Pharmaceuticals are currently conducting phase I clinical and preclinical trials with oral insulin and exenatide mucoadhesive nanoparticles. NanoMega Corp have encapsulated insulin in chitosan shelled gamma $\gamma$-PGA nanoparticles and Oshadi drug administration have blended insulin with inert silica nanoparticles, a polysaccharide, suspended them in oil and loaded into enteric capsules.

\subsection{Conclusion}

Oral bioavailabilities of peptide and protein drugs are generally very low, table 1 . Despite oral delivery being the most desirous drug delivery route very few peptide and protein drugs are orally available. The main obstacles to oral peptide and protein delivery, stability and permeability, vary amongst peptides and proteins and differ in the various segments of the GI tract. Analysis of these can identify the best candidates for oral delivery and the segments of the GI tract to be targeted for drug release and absorption.

Reviewing the studies of peptide and protein stability in gastric and small intestinal fluids revealed that small peptides were most stable and some of these may not need any gastric protection. Contrary to this trend larger proteins appeared more stable in simulated small intestinal fluids than small proteins and large peptides. They were however susceptible to gastric denaturation so would require enteric protection. There was no apparent correlation between stability in large intestinal fluids and peptide/protein size or structure. The majority of peptides and proteins tested were vulnerable to digestion by gastric, small intestinal and 
large intestinal fluids and will need protection to enable their oral delivery. A review of peptide/protein intestinal permeability revealed permeability reduced with increasing size, hydrophilicity and $\mathrm{H}$ bonding potential.

The small intestine presented the greatest enzymatic barrier to oral peptide and protein delivery. Of the small intestinal segments the jejunum was most proteolytic. While the large intestine and stomach may be more favourable for oral delivery for some proteins and peptides as they have a lower stability barrier they are not as permeable as the small intestine. The proximal small intestine appeared the most favourable segment for uptake in humans, possibly due to wider paracellular channels here.

While many drug delivery strategies have been developed very few have reached clinical trials. Those that have and that have the greatest potential for becoming commercially available are those for peptides with a wide therapeutic window and which use multiple approaches for protection and permeation. The number of discontinued trials indicates that oral systemic delivery is a huge challenge, particularly for proteins, and while oral delivery may soon be a reality for peptides for proteins this goal remains currently out of reach.

\subsection{Expert Opinion}

The goal of universal peptide and protein drug delivery has been pursued since the discovery of insulin 90 years ago but as yet very few are orally available. With the pharmaceutical industry increasingly focussed on biological drugs the drive for oral peptide and protein drugs has never been greater. The achievement of oral delivery for all peptide and protein drugs would elicit huge improvements in the quality of life of patients who rely on chronic, injectable doses of therapeutic peptides and proteins. It would also mean cost savings in terms of production and administration for the non-sterile, oral formulations. 
To achieve universal oral peptide and protein drug delivery greater understanding of their gastrointestinal stability and permeability and what affects these is needed. This will enable better selection of drug candidates, targeting of optimal gastrointestinal regions for uptake and improved formulation selection. While peptide and protein drugs have been tested in simulated and animal gastrointestinal fluids/tissues there has been limited testing in human fluids/tissues and this will be needed to increase the chance of success in humans. There have been very few oral formulations which have been clinically trialled compared to all the delivery strategies which have been developed and tested in vitro and in animals. More trials in humans are needed to increase the likelihood of oral delivery success.

The strategies which have proved most successful in clinical trials are combinations of many strategies. They combine encapsulation of the protein/peptide drug in multiparticulates, capsules or tablets with protease inhibitors and permeability enhancers, especially medium chain fatty acids. They may also be enteric coated or conjugated to targeting ligands.

As many of these delivery strategies may disrupt normal digestive processes and compromise the barrier function of the GI tract to incoming toxins implications of their long term use should be considered. Oral bioavailabilities should be reproducible and reliable to achieve a regulatory filing but incompatibility of hydrophilic peptide and protein drugs with hydrophobic delivery carriers can produce uncontrolled drug release ${ }^{46}$. Reproducible bioavailabilities may also be compromised by intra or inter subject variation in the GI environment as peptide and protein drug absorption is so highly dependent on its characteristics. Those drugs with a wide therapeutic window, such as the currently orally available desmopressin, may be more compatible for oral delivery due to this variability. Octreotide and calcitonin have large therapeutic windows and this may partly explain the progression of their oral formulations to phase III clinical trials. 
Despite the failures encountered during clinical trials and the suspension of many projects oral peptide/protein drug formulations are likelier than they ever have been. The success of Tarsa Therapeutics' oral salmon calcitonin in clinical trials increases the probability that other peptide and protein drugs will soon be orally available.

Oral bioavailabilities are still much lower than those of injected doses and therefore much higher doses must be administered orally to have the same effect. For more expensive peptide and protein drugs this could preclude their oral delivery. The toxicity implications of administering relatively large doses of peptide and protein drugs orally must also be considered.

Challenges for the future may be the scaling up for manufacture of the more complex formulations. Research and clinical trials have mainly focused on the delivery of oral peptides rather than proteins. Their larger size seems to multiply the challenges of oral delivery and this may have deterred development. While oral peptide delivery may soon be more widely available oral protein delivery to the systemic circulation may take longer and require strategies more specifically designed for them.

\section{Article Highlights}

- Peptide and protein drugs represent a large and growing share of the pharmaceutical market yet few are orally available.

- Poor gastrointestinal stability and permeability are factors in the low oral bioavailability of peptide and protein drugs but there are few human studies investigating their gastrointestinal stability and permeability.

- Studies in simulated, animal and some human gastrointestinal fluids and tissues reveal that the smallest peptides are most suited to oral delivery and that some of these may not require enteric protection. 
- The small intestine is the most degradative environment for the widest range of peptides and proteins but it is more permeable than the stomach or large intestine.

- Numerous oral peptide and protein drug delivery strategies have been investigated but few have been clinically trialled. The most successful trials utilised multiple approaches for enhanced stabilisation and permeation and involved peptides with wide therapeutic windows.

- Very few clinical trials have involved delivery of large proteins therefore it appears unlikely these will be available orally soon.

\section{Bibliography}

1. IMAP. Pharmaceuticals and Biotech Industry Global Report 2011. 2011.

2. Top 20 Best-Selling Drugs of 2012. 2013 [cited 20148 February 2014]; Available from: www.genengnews.com

3. Pichereau C, Allary C. Therapeutic peptides under the spotlight. 2005.

4. Reichert J, Pechen, P., Tartar, A., Dunn, M.K. Development trends for peptide therapeutics- A comprehensive quantitative analysis of peptide therapeutics in clinical development. Peptide Therapeutics Foundation 2010:1-11.

5. McConnell EL, Fadda HM, Basit AW. Gut instincts: explorations in intestinal physiology and drug delivery. Int J Pharm 2008 Dec 8;364(2):213-26.

6. Busby RW, Kessler MM, Bartolini WP, Bryant AP, Hannig G, Higgins CS, et al. Pharmacologic properties, metabolism, and disposition of linaclotide, a novel therapeutic peptide approved for the treatment of irritable bowel syndrome with constipation and chronic idiopathic constipation. J Pharmacol Exp Ther 2013 Jan;344(1):196-206. 
7. Ito Y, Yoshimura M, Tanaka T, Takada K. Effect of lipophilicity on the bioavailability of drugs after percutaneous administration by dissolving microneedles. $\mathrm{J}$ Pharm Sci 2011 Mar;101(3):1145-56.

8. Cui X, Cao D, Qu C, Zhang X, Zheng A. A study of the chemical and biological stability of vasoactive intestinal peptide. Drug Dev Ind Pharm 2013 Dec;39(12):1907-10.

9. Fjellestad-Paulsen A, Soderberg-Ahlm C, Lundin S. Metabolism of vasopressin, oxytocin, and their analogues in the human gastrointestinal tract. Peptides 1995;16(6):1141-7.

10. Wen JY, Ledger R, McLeod BJ, Davies NM, Butt AG, Tucker IG. Protein and peptide degradation in the intestine of the common brushtail possum (Trichosurus vulpecula). J Comp Physiol B 2002 Oct;172(7):553-9.

11. Tozaki H, Odoriba T, Iseki T, Taniguchi T, Fujita T, Murakami M, et al. Use of protease inhibitors to improve calcitonin absorption from the small and large intestine in rats. J Pharm Pharmacol 1998 Aug;50(8):913-20.

12. Wen JY, Ledger R, Butt AG, McLeod BJ, Davies NM, Tucker IG. Inhibition of proteolysis in luminal extracts from the intestine of the brushtail possum. J Pharm Pharmacol 2002 Oct;54(10):1365-72.

13. Wen JY, Ledger R, McLeod BJ, Davies NM, Butt AG, Tucker IG. Enzymatic degradation of luteinizing hormone releasing hormone (LHRH) by mucosal homogenates from the intestine of the common brushtail possum (Trichosurus vulpecula). Life Sci 2002 Nov 8;71(25):3019-30.

14. Haupt S, Gil E, Tirosh R, Klinger E, Gad A, Rubinstein A. Regional peptide uptake study in the rat intestinal mucosa: glatiramer acetate as a model drug. Pharm Res 2002 Jun;19(6):832-7. 
15. Ungell AL, Andreasson A, Lundin K, Utter L. Effects of Enzymatic Inhibition and Increased Paracellular Shunting on Transport of Vasopressin Analogs in the Rat. Journal of Pharmaceutical Sciences 1992 Jul;81(7):640-5.

16. Russell-Jones GJ, Westwood SW, Habberfield AD. Vitamin B12 mediated oral delivery systems for granulocyte-colony stimulating factor and erythropoietin. Bioconjug Chem 1995 Jul-Aug;6(4):459-65.

17. Torres-Lugo M, Garcia M, Record R, Peppas NA. pH-Sensitive hydrogels as gastrointestinal tract absorption enhancers: transport mechanisms of salmon calcitonin and other model molecules using the Caco-2 cell model. Biotechnol Prog 2002 MayJun;18(3):612-6.

18. Yoo HS, Park TG. Biodegradable nanoparticles containing protein-fatty acid complexes for oral delivery of salmon calcitonin. Journal of Pharmaceutical Sciences 2004 Feb;93(2):488-95.

19. Foger F, Kopf A, Loretz B, Albrecht K, Bernkop-Schnurch A. Correlation of in vitro and in vivo models for the oral absorption of peptide drugs. Amino Acids 2008 Jun;35(1):233-41.

20. Humphrey MJ, Ringrose PS. Peptides and related drugs: a review of their absorption, metabolism, and excretion. Drug Metab Rev 1986;17(3-4):283-310.

21. McMartin C, Hutchinson LE, Hyde R, Peters GE. Analysis of structural requirements for the absorption of drugs and macromolecules from the nasal cavity. J Pharm Sci 1987 Jul;76(7):535-40.

22. Donovan MD, Flynn GL, Amidon GL. Absorption of polyethylene glycols 600 through 2000: the molecular weight dependence of gastrointestinal and nasal absorption. Pharm Res 1990 Aug;7(8):863-8. 
23. Jung T, Kamm W, Breitenbach A, Kaiserling E, Xiao JX, Kissel T. Biodegradable nanoparticles for oral delivery of peptides: is there a role for polymers to affect mucosal uptake? Eur J Pharm Biopharm 2000 Jul;50(1):147-60.

24. Conradi RA, Hilgers AR, Ho NF, Burton PS. The influence of peptide structure on transport across Caco-2 cells. Pharm Res 1991 Dec;8(12):1453-60.

25. Kim DC, Burton PS, Borchardt RT. A correlation between the permeability characteristics of a series of peptides using an in vitro cell culture model (Caco-2) and those using an in situ perfused rat ileum model of the intestinal mucosa. Pharm Res 1993 Dec;10(12):1710-4.

26. Ritschel WA. Microemulsions for improved peptide absorption from the gastrointestinal tract. Methods Find Exp Clin Pharmacol 1991 Apr;13(3):205-20.

27. Hee Lee Y, Leesman GD, Makhey V, Yu H, Hu P, Perry B, et al. Regional oral absorption, hepatic first-pass effect, and non-linear disposition of salmon calcitonin in beagle dogs. Eur J Pharm Biopharm 2000 Sep;50(2):205-11.

28. Sinko PJ, Lee YH, Makhey V, Leesman GD, Sutyak JP, Yu H, et al. Biopharmaceutical approaches for developing and assessing oral peptide delivery strategies and systems: in vitro permeability and in vivo oral absorption of salmon calcitonin ( $\mathrm{sCT}$ ). Pharm Res 1999 Apr;16(4):527-33.

29. Wu L, Zhang G, Lu Q, Sun Q, Wang M, Li N, et al. Evaluation of salmon calcitonin (sCT) enteric-coated capsule for enhanced absorption and GI tolerability in rats. Drug Dev Ind Pharm 2010 Mar;36(3):362-70.

30. Sasaki I, Fujita T, Murakami M, Yamamoto A, Nakamura E, Imasaki H, et al. Intestinal absorption of azetirelin, a new thyrotropin-releasing hormone (TRH) analogue. I. Possible factors for the low oral bioavailability in rats. Biol Pharm Bull 1994 Sep;17(9):125661. 
31. d'Agay-Abensour L, Fjellestad-Paulsen A, Hoglund P, Ngo Y, Paulsen O, Rambaud JC. Absolute bioavailability of an aqueous solution of 1-deamino-8-D-arginine vasopressin from different regions of the gastrointestinal tract in man. Eur J Clin Pharmacol 1993;44(5):473-6.

32. Han L, Zhao Y, Yin L, Li R, Liang Y, Huang H, et al. Insulin-Loaded pH-Sensitive Hyaluronic Acid Nanoparticles Enhance Transcellular Delivery. AAPS PharmSciTech 2012 Sep;13(3):836-45.

33. Lundin S, Pantzar N, Broeders A, Ohlin M, Westrom BR. Differences in transport rate of oxytocin and vasopressin analogues across proximal and distal isolated segments of the small intestine of the rat. Pharm Res 1991 Oct;8(10):1274-80.

34. Pantzar N, Lundin S, Westrom BR. Different properties of the paracellular pathway account for the regional small intestinal permeability to the peptide desmopressin. J Pharm Sci 1995 Oct;84(10):1245-8.

35. Zheng Y, Qiu Y, Lu MF, Hoffman D, Reiland TL. Permeability and absorption of leuprolide from various intestinal regions in rabbits and rats. Int J Pharm 1999 Aug $5 ; 185(1): 83-92$.

36. Kohler E, Duberow-Drewe M, Drewe J, Ribes G, Loubatieres-Mariani MM, Mazer N, et al. Absorption of an aqueous solution of a new synthetic somatostatin analogue administered to man by gavage. Eur J Clin Pharmacol 1987;33(2):167-71.

37. Gebert A, Steinmetz I, Fassbender S, Wendlandt KH. Antigen transport into Peyer's patches: increased uptake by constant numbers of M cells. Am J Pathol 2004 Jan;164(1):6572.

38. Gupta S, Jain A, Chakraborty M, Sahni JK, Ali J, Dang S. Oral delivery of therapeutic proteins and peptides: a review on recent developments. Drug Deliv 2013 Aug;20(6):237-46. 
39. Shaji J, Patole V. Protein and Peptide Drug Delivery: Oral Approaches. Indian J Pharm Sci 2008 May-Jun;70(3):269-77.

40. Singh R, Singh S, Lillard JW, Jr. Past, present, and future technologies for oral delivery of therapeutic proteins. J Pharm Sci 2008 Jul;97(7):2497-523.

41. Lee HJ. Protein drug oral delivery: the recent progress. Arch Pharm Res 2002 Oct;25(5):572-84.

42. Leone-Bay A, Sato M, Paton D, Hunt AH, Sarubbi D, Carozza M, et al. Oral delivery of biologically active parathyroid hormone. Pharm Res 2001 Jul;18(7):964-70.

43. Milstein SJ, Leipold H, Sarubbi D, Leone-Bay A, Mlynek GM, Robinson JR, et al. Partially unfolded proteins efficiently penetrate cell membranes--implications for oral drug delivery. J Control Release 1998 Apr 30;53(1-3):259-67.

44. Leone-Bay A, McInnes C, Wang N, DeMorin F, Achan D, Lercara C, et al. Microsphere formation in a series of derivatized alpha-amino acids: properties, molecular modeling, and oral delivery of salmon calcitonin. J Med Chem 1995 Oct 13;38(21):4257-62. 45. Binkley N, Bolognese M, Sidorowicz-Bialynicka A, Vally T, Trout R, Miller C, et al. A phase 3 trial of the efficacy and safety of oral recombinant calcitonin: the Oral Calcitonin in Postmenopausal Osteoporosis (ORACAL) trial. Journal of bone and mineral research : the official journal of the American Society for Bone and Mineral Research 2012 Aug;27(8):1821-9.

46. Yang R, Gao R, Li F, He H, Tang X. The influence of lipid characteristics on the formation, in vitro release, and in vivo absorption of protein-loaded SLN prepared by the double emulsion process. Drug Dev Ind Pharm 2011 Feb;37(2):139-48.

47. Sasaki I, Tamura T, Shibakawa T, Fujita T, Murakami M, Yamamoto A, et al. Metabolism of azetirelin, a new thyrotropin-releasing hormone (TRH) analogue, by intestinal microorganisms. Pharm Res 1997 Aug;14(8):1004-7. 
48. Anderson KE, Eliot LA, Stevenson BR, Rogers JA. Formulation and evaluation of a folic acid receptor-targeted oral vancomycin liposomal dosage form. Pharm Res 2001 Mar;18(3):316-22.

49. Fricker G, Bruns C, Munzer J, Briner U, Albert R, Kissel T, et al. Intestinal absorption of the octapeptide SMS 201-995 visualized by fluorescence derivatization. Gastroenterology 1991 Jun;100(6):1544-52.

50. Michael S, Thole M, Dillmann R, Fahr A, Drewe J, Fricker G. Improvement of intestinal peptide absorption by a synthetic bile acid derivative, cholylsarcosine. Eur J Pharm Sci 2000 Apr;10(2):133-40.

51. Thanou M, Verhoef JC, Marbach P, Junginger HE. Intestinal absorption of octreotide: N-trimethyl chitosan chloride (TMC) ameliorates the permeability and absorption properties of the somatostatin analogue in vitro and in vivo. J Pharm Sci 2000 Jul;89(7):951-7.

52. Adjei A, Love S, Johnson E, Diaz G, Greer J, Haviv F, et al. Effect of formulation adjuvants on gastrointestinal absorption of leuprolide acetate. J Drug Target 1993;1(3):251-8. 53. Iqbal J, Vigl C, Moser G, Gasteiger M, Perera G, Bernkop-Schnurch A. Development and in vivo evaluation of a new oral nanoparticulate dosage form for leuprolide based on polyacrylic acid. Drug Deliv 2011 Aug;18(6):432-40.

54. Iqbal J, Shahnaz G, Perera G, Hintzen F, Sarti F, Bernkop-Schnurch A. Thiolated chitosan: development and in vivo evaluation of an oral delivery system for leuprolide. Eur $\mathbf{J}$ Pharm Biopharm 2012 Jan;80(1):95-102.

55. Luessen HL, de Leeuw BJ, Langemeyer MW, de Boer AB, Verhoef JC, Junginger HE. Mucoadhesive polymers in peroral peptide drug delivery. VI. Carbomer and chitosan improve the intestinal absorption of the peptide drug buserelin in vivo. Pharm Res 1996 Nov;13(11):1668-72. 
56. Thanou M, Florea BI, Langemeyer MW, Verhoef JC, Junginger HE. N-trimethylated chitosan chloride (TMC) improves the intestinal permeation of the peptide drug buserelin in vitro (Caco-2 cells) and in vivo (rats). Pharm Res 2000 Jan;17(1):27-31.

57. Lundin S, Folkesson HG, Pierzynovski SG, Bengtsson HI. Gastrointestinal absorption and plasma clearance rates of [D-Arg8]vasopressin analogues in the rat. Peptides 1994;15(5):809-14.

58. Fjellestad-Paulsen A, d'Agay-Abensour L, Hoglund P, Rambaud JC. Bioavailability of 1-deamino-8-D-arginine vasopressin with an enzyme inhibitor (aprotinin) from the small intestine in healthy volunteers. Eur J Clin Pharmacol 1996;50(6):491-5.

59. Jaiswal J, Gupta SK, Kreuter J. Preparation of biodegradable cyclosporine nanoparticles by high-pressure emulsification-solvent evaporation process. J Control Release 2004 Apr 16;96(1):169-78.

60. Ogiso T, Funahashi N, Tsukioka Y, Iwaki M, Tanino T, Wada T. Oral delivery of synthetic eel calcitonin, elcatonin, in rats. Biol Pharm Bull 2001 Jun;24(6):656-61.

61. Tozaki H, Nishioka J, Komoike J, Okada N, Fujita T, Muranishi S, et al. Enhanced absorption of insulin and $(\mathrm{Asu}(1,7))$ eel-calcitonin using novel azopolymer-coated pellets for colon-specific drug delivery. J Pharm Sci 2001 Jan;90(1):89-97.

62. Fetih G, Fausia H, Okada N, Fujita T, Attia M, Yamamoto A. Colon-specific delivery and enhanced colonic absorption of $[\mathrm{Asu}(1,7)]$-eel calcitonin using chitosan capsules containing various additives in rats. J Drug Target 2006 Apr;14(3):165-72.

63. Sinko PJ, Smith CL, McWhorter LT, Stern W, Wagner E, Gilligan JP. Utility of pharmacodynamic measures for assessing the oral bioavailability of peptides. 1 . Administration of recombinant salmon calcitonin in rats. J Pharm Sci 1995 Nov;84(11):13748. 
64. du Plessis LH, Lubbe J, Strauss T, Kotze AF. Enhancement of nasal and intestinal calcitonin delivery by the novel Pheroid fatty acid based delivery system, and by N-trimethyl chitosan chloride. Int J Pharm 2010 Jan 29;385(1-2):181-6.

65. Hastewell J, Lynch S, Williamson I, Fox R, Mackay M. Absorption of human calcitonin across the rat colon in vivo. Clin Sci (Lond) 1992 May;82(5):589-94.

66. Buclin T, Cosma Rochat M, Burckhardt P, Azria M, Attinger M. Bioavailability and biological efficacy of a new oral formulation of salmon calcitonin in healthy volunteers. $\mathrm{J}$ Bone Miner Res 2002 Aug;17(8):1478-85.

67. Hastewell J, Antonin KH, Fox R, Mackay M. The colonic absorption of human calcitonin: The effects of increasing local concentration and co-administration with a protease inhibitor. International Journal of Pharmaceutics 1995 Dec 29;126(1-2):245-51.

68. Jin CH, Chae SY, Son S, Kim TH, Um KA, Youn YS, et al. A new orally available glucagon-like peptide-1 receptor agonist, biotinylated exendin-4, displays improved hypoglycemic effects in db/db mice. J Control Release 2009 Feb 10;133(3):172-7. 69. Gedulin BR, Smith PA, Jodka CM, Chen K, Bhavsar S, Nielsen LL, et al. Pharmacokinetics and pharmacodynamics of exenatide following alternate routes of administration. Int J Pharm 2008 May 22;356(1-2):231-8.

70. Takeuchi H, Yamamoto H, Niwa T, Hino T, Kawashima Y. Enteral absorption of insulin in rats from mucoadhesive chitosan-coated liposomes. Pharm Res 1996 Jun;13(6):896-901.

71. Yamamoto A, Tanaka H, Okumura S, Shinsako K, Ito M, Yamashita M, et al. Evaluation of insulin permeability and effects of absorption enhancers on its permeability by an in vitro pulmonary epithelial system using Xenopus pulmonary membrane. Biol Pharm Bull 2001 Apr;24(4):385-9. 
72. Eaimtrakarn S, Rama Prasad YV, Ohno T, Konishi T, Yoshikawa Y, Shibata N, et al. Absorption enhancing effect of labrasol on the intestinal absorption of insulin in rats. J Drug Target 2002 May;10(3):255-60.

73. Guo L, Ma E, Zhao H, Long Y, Zheng C, Duan M. Preliminary evaluation of a novel oral delivery system for rhPTH1-34: in vitro and in vivo. Int J Pharm 2011 Nov $25 ; 420(1): 172-9$.

74. Venkatesan N, Uchino K, Amagase K, Ito Y, Shibata N, Takada K. Gastro-intestinal patch system for the delivery of erythropoietin. J Control Release 2006 Mar 10;111(1-2):1926.

75. Bayley D, Temple C, Clay V, Steward A, Lowther N. The transmucosal absorption of recombinant human interferon-alpha B/D hybrid in the rat and rabbit. J Pharm Pharmacol 1995 Sep;47(9):721-4.

76. Jensen-Pippo KE, Whitcomb KL, DePrince RB, Ralph L, Habberfield AD. Enteral bioavailability of human granulocyte colony stimulating factor conjugated with poly(ethylene glycol). Pharm Res 1996 Jan;13(1):102-7.

77. Moore JA, Pletcher, S.A., Ross, M. Absorption enhancement of growth hormone from the gastrointestinal tract of rats. Int J Pharm 1986;34:35-43.

78. Khomane K, Kumar L, Meena CL, Jain R, Bansal A. NP-647, a novel TRH analogue: investigating physicochemical parameters critical for its oral and parenteral delivery. Int $\mathbf{J}$ Pharm 2011 Mar 15;406(1-2):21-30.

79. Kafka AP, McLeod BJ, Rades T, McDowell A. Release and bioactivity of PACA nanoparticles containing D-Lys-GnRH for brushtail possum fertility control. J Control Release 2011 Feb 10;149(3):307-13.

80. Werle M, Samhaber A, Bernkop-Schnurch A. Degradation of teriparatide by gastrointestinal proteolytic enzymes. J Drug Target 2006 Apr;14(3):109-15. 
81. Jain S, Rathi VV, Jain AK, Das M, Godugu C. Folate-decorated PLGA nanoparticles as a rationally designed vehicle for the oral delivery of insulin. Nanomedicine (Lond) 2012 May 14.

82. Werle M, Kolmar H, Albrecht R, Bernkop-Schnurch A. Characterisation of the barrier caused by luminally secreted gastro-intestinal proteolytic enzymes for two novel cystine-knot microproteins. Amino Acids 2008 Jun;35(1):195-200.

83. Zheng C, Liu Y, Zhou Q, Di X. Capillary electrophoresis with noncovalently bilayercoated capillaries for stability study of allergenic proteins in simulated gastrointestinal fluids. J Chromatogr B Analyt Technol Biomed Life Sci 2010 Oct 15;878(28):2933-6.

84. Massicotte LP, Baille WE, Mateescu MA. Carboxylated high amylose starch as pharmaceutical excipients. Structural insights and formulation of pancreatic enzymes. Int $\mathbf{J}$ Pharm 2008 May 22;356(1-2):212-23.

85. Scocca S, Faustini M, Villani S, Munari E, Conte U, Russo V, et al. Alginate/polymethacrylate copolymer microparticles for the intestinal delivery of enzymes. Curr Drug Deliv 2007 Apr;4(2):103-8.

86. Li XY, Jin LJ, Uzonna JE, Li SY, Liu JJ, Li HQ, et al. Chitosan-alginate microcapsules for oral delivery of egg yolk immunoglobulin (IgY): in vivo evaluation in a pig model of enteric colibacillosis. Vet Immunol Immunopathol 2009 May 15;129(1-2):1326.

87. Thwaites DT, Simmons NL, Hirst BH. Thyrotropin-releasing hormone (TRH) uptake in intestinal brush-border membrane vesicles: comparison with proton-coupled dipeptide and $\mathrm{Na}(+)$-coupled glucose transport. Pharm Res 1993 May;10(5):667-73.

88. Fagerholm U, Sjostrom B, Sroka-Markovic J, Wijk A, Svensson M, Lennernas H. The effect of a drug-delivery system consisting of soybean phosphatidyl choline and medium- 
chain monoacylglycerol on the intestinal permeability of hexarelin in the rat. J Pharm Pharmacol 1998 May;50(5):467-73.

89. Lundin S, Bengtsson HI, Folkesson HG, Westrom BR. Degradation of [mercaptopropionic acid1, D-arginine8]-vasopressin (dDAVP) in pancreatic juice and intestinal mucosa homogenate. Pharmacol Toxicol 1989 Aug;65(2):92-5.

90. Guo J, Ping Q, Jiang G, Dong J, Qi S, Feng L, et al. Transport of leuprolide across rat intestine, rabbit intestine and Caco-2 cell monolayer. Int J Pharm 2004 Jul 8;278(2):415-22. 91. Zheng Y, FuLu MY, Qiu Y, Reiland TL. Enzymatic degradation of leuprolide in rat intestinal mucosal homogenates. Pharm Dev Technol 1999;4(4):539-44.

92. Lee HE, Lee MJ, Park CR, Kim AY, Chun KH, Hwang HJ, et al. Preparation and characterization of salmon calcitonin-sodium triphosphate ionic complex for oral delivery. $\mathrm{J}$ Control Release 2010 Apr 19;143(2):251-7.

93. Lu RH, Kopeckova P, Kopecek J. Degradation and aggregation of human calcitonin in vitro. Pharm Res 1999 Mar;16(3):359-67.

94. Youn YS, Jung JY, Oh SH, Yoo SD, Lee KC. Improved intestinal delivery of salmon calcitonin by Lys18-amine specific PEGylation: stability, permeability, pharmacokinetic behavior and in vivo hypocalcemic efficacy. J Control Release 2006 Sep 12;114(3):334-42.

95. Youn YS, Chae SY, Lee S, Kwon MJ, Shin HJ, Lee KC. Improved peroral delivery of glucagon-like peptide-1 by site-specific biotin modification: design, preparation, and biological evaluation. Eur J Pharm Biopharm 2008 Mar;68(3):667-75.

96. Chae SY, Jin CH, Shin HJ, Youn YS, Lee S, Lee KC. Preparation, characterization, and application of biotinylated and biotin-PEGylated glucagon-like peptide-1 analogues for enhanced oral delivery. Bioconjug Chem 2008 Jan;19(1):334-41.

97. Tozaki H, Emi Y, Horisaka E, Fujita T, Yamamoto A, Muranishi S. Degradation of insulin and calcitonin and their protection by various protease inhibitors in rat caecal 
contents: implications in peptide delivery to the colon. J Pharm Pharmacol 1997 Feb;49(2):164-8.

98. Tozaki H, Emi Y, Horisaka E, Fujita T, Yamamoto A, Muranishi S. Metabolism of peptide drugs by the microorganisms in rat cecal contents. Biol Pharm Bull 1995 Jun;18(6):929-31.

99. Soltero R, Ekwuribe N. The oral delivery of protein and peptide drugs. Innovations in Pharmaceutical Technology 2001.

100. Eldor R, Kidron M, Greenberg-Shushlav Y, Arbit E. Novel glucagon-like peptide-1 analog delivered orally reduces postprandial glucose excursions in porcine and canine models. J Diabetes Sci Technol 2010 Nov;4(6):1516-23. 
ailabilities of peptide/protein drugs when administered orally or to intestinal segments in humans/animals

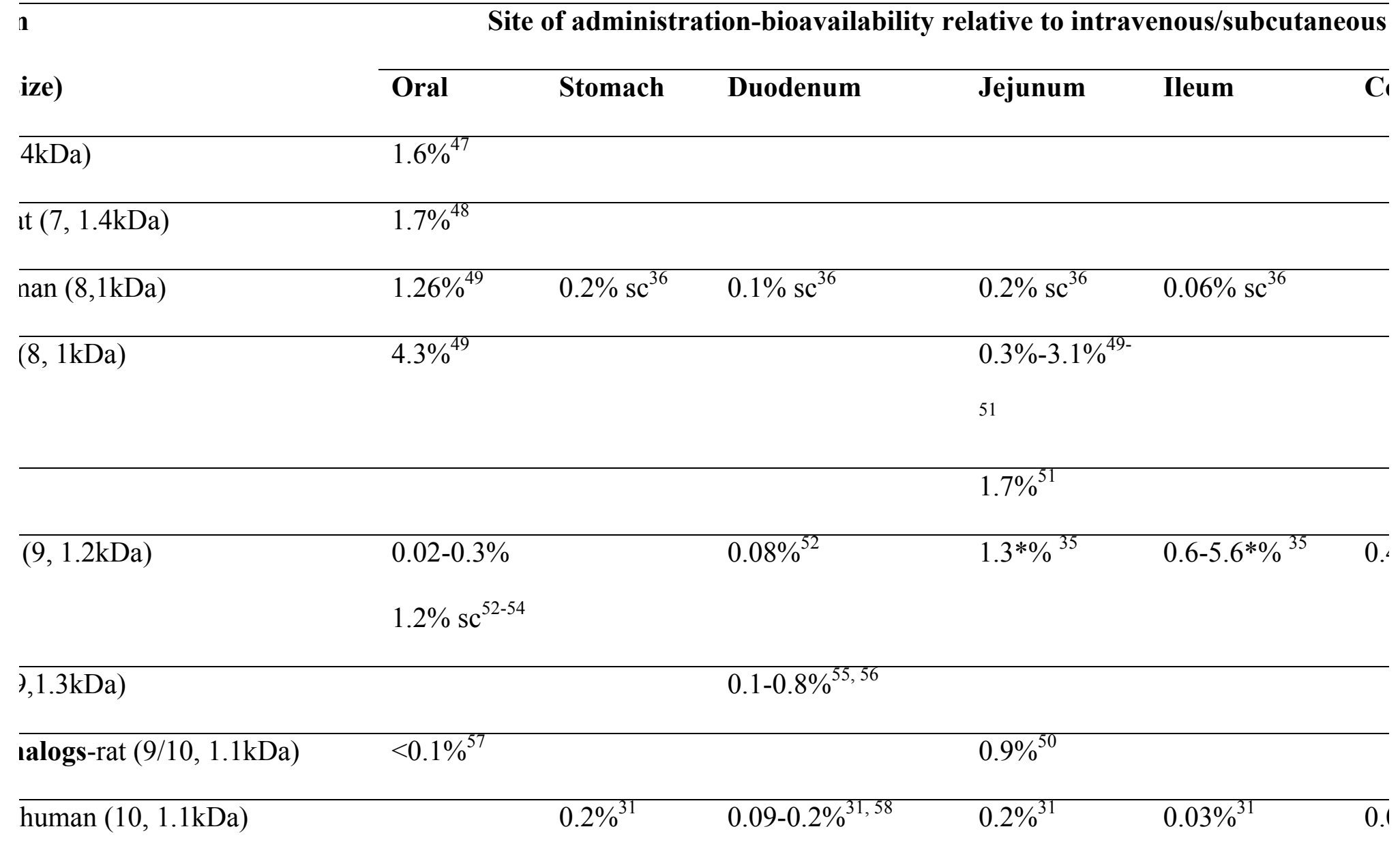




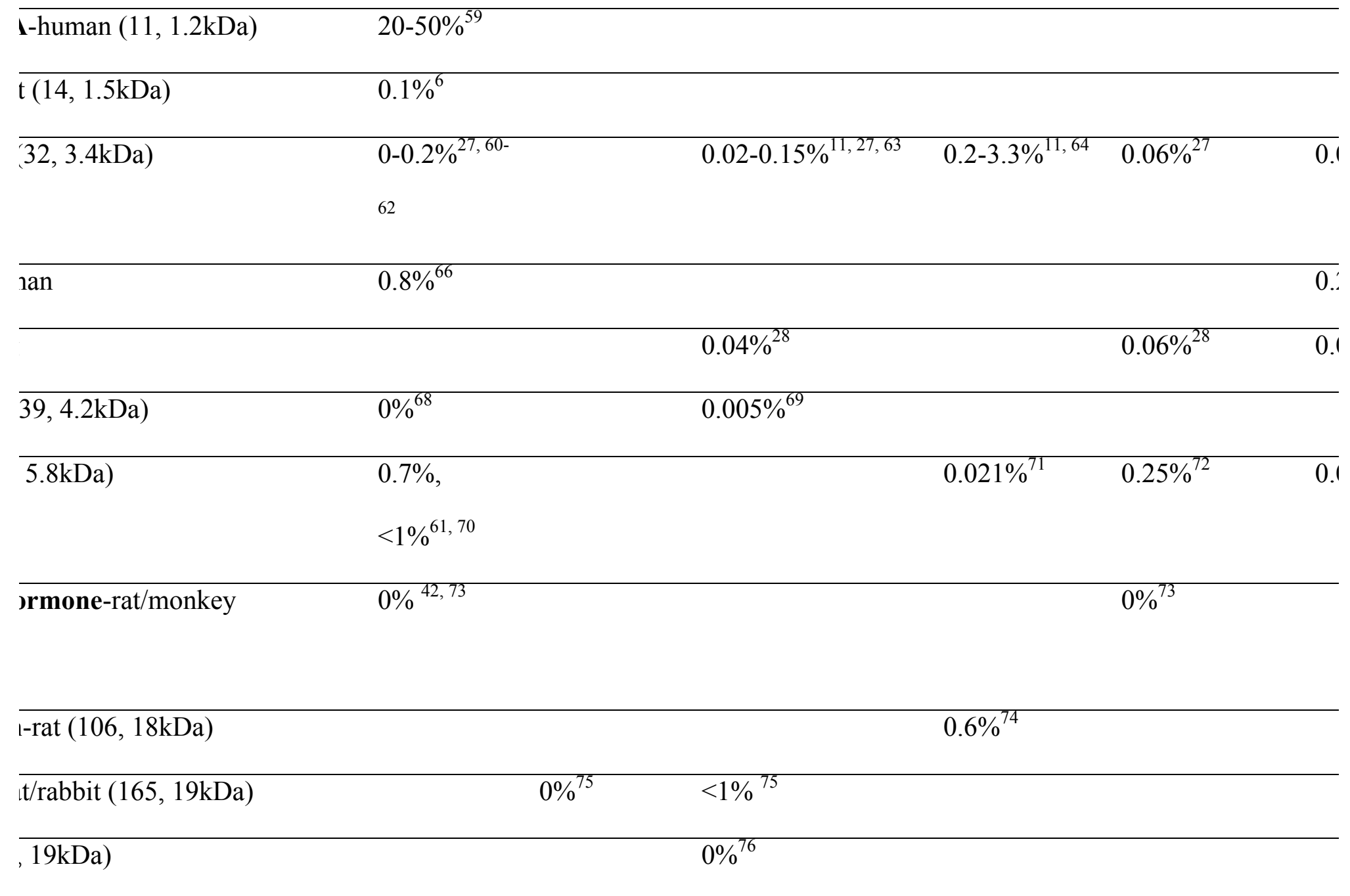


h Hormone rat $(191,22 \mathrm{kDa})$

$0.8 \%{ }^{77}$

$1.0 \%{ }^{77}$

$0.7 \%{ }^{77}$

0.

d rats. Thyrotropin releasing hormone (TRH), granulocyte colony stimulating factor (GCSF).

s are relative to an intravenous dose, unless specified as relative to a subcutaneous dose (sc). 
2/protein recovery after incubation in simulated gastric fluid (SGF), human/animal gastric fluid and mucosa

\begin{tabular}{|c|c|c|c|c|}
\hline \multirow{2}{*}{ ize) } & \multicolumn{4}{|c|}{ Proportion intact/active after incubation in simulated/human/animal gastı } \\
\hline & SGF no pepsin & SGF pepsin & Gastric fluid & $\overline{\text { Gas }}$ \\
\hline a) & & $100 \% 2$ hours $^{47,78}$ & $100 \%-2$ hours rat ${ }^{47,78}$ & \\
\hline Da) & & & $100 \%$ human $^{9}$ & 100 \\
\hline $7 / 10,1.1 \mathrm{kDa})$ & & & $100 \%$ human $^{9}$ & 100 \\
\hline $1.2 \mathrm{kDa})$ & & $60 \%, 6$ hours $^{79}$ & & \\
\hline , $1.5 \mathrm{kDa})$ & $100 \% 3 \mathrm{hrs}^{6}$ & $100 \% 3$ hours $^{6}$ & & \\
\hline stinal peptide $(28,3.3 \mathrm{kDa})$ & $100 \%^{8}$ & $0 \%$ immediate $^{8}$ & & \\
\hline $34,4.1 \mathrm{kDa})$ & & $0 \% 5$ mins $^{80}$ & & \\
\hline$\overline{\mathrm{kDa})}$ & & $\begin{array}{l}3 \%-10 \% 2 \text { hours }^{32,81} \\
0 \% 3 \text { minutes }^{82}\end{array}$ & $0 \% 3$ mins- pig $^{82}$ & \\
\hline , $14.3 \mathrm{kDa})$ & $0 \% 30$ mins $^{83}$ & & & \\
\hline I A/B $(162,18.4 \mathrm{kDa})$ & $17.2-34.3 \% 60 \operatorname{mins}^{83}$ & $0 \% 2 \operatorname{mins}^{83}$ & & \\
\hline
\end{tabular}




\begin{tabular}{|c|c|}
\hline$\overline{\mathrm{kDa})}$ & $0 \%$ immediate $^{83}$ \\
\hline \multirow{2}{*}{ ormone $(84,9.4 \mathrm{kDa})$} & $0 \% 5 \mathrm{~min}^{73}$ \\
\hline & $8 \% 30 \operatorname{mins}^{84}$ \\
\hline i-50kDa) & $0 \% 30 \mathrm{mins}, 3 \% 10 \mathrm{mins}^{84}$ \\
\hline $51-54 \mathrm{kDa})$ & $0 \%, 30$ mins, $2 \% 5 \operatorname{mins}^{84}$ \\
\hline$\overline{\mathrm{kDa})}$ & $0 \%$ immediate $^{83}$ \\
\hline llk immunoglobulin (150kDa) & $0 \% 1$ hour $^{86}$ \\
\hline
\end{tabular}

mone releasing hormone (LHRH) 
e/protein recovery and half lives (HL) in simulated intestinal fluid (SIF), human/animal small intestinal fluid and mucosc

\begin{tabular}{|c|c|c|c|}
\hline \multirow{2}{*}{$\begin{array}{l}\text { s/protein } \\
\text { Icids, size) }\end{array}$} & \multicolumn{3}{|c|}{ Proportion remaining and half lives after incubation in human/animal small intestinal flui } \\
\hline & SIF & Small intestinal fluid & Small intestinal mucosa \\
\hline a) & $100 \%, 3 \mathrm{hrs}^{78}$ & Rat proximal- $100 \%{ }^{47}$ & Rat-100\% ${ }^{47}$ Rabbit jejunal-94\% \\
\hline $.9 \mathrm{kDa})$ & & Rat jejunal/ileal- $80 \% / 60 \% 1 \mathrm{hr}^{88}$ & \\
\hline $1 \mathrm{kDa})$ & & & Rat- $100 \%{ }^{49}$ \\
\hline ggs $(9,1 \mathrm{kDa})$ & & Human ileal- $0 \% 60$ mins $^{9}$ & Human jejunal/ileal $100 \%{ }^{9}$ \\
\hline \multirow[t]{3}{*}{$\operatorname{talogs}(9 / 10$} & & Human ileal $0 \% 30$ mins $^{9}$ & Human jejunal-30\% 3hrs, \\
\hline & & Rat- $0.2-58.3 \% 30$ mins $^{57}$ & ileal $100 \% 3 \mathrm{hrs}^{9}$ \\
\hline & & Pig pancreatic juice $0 \% 5$ mins $^{89}$ & Rabbit 2 mins and 40 mins half \\
\hline \multirow[t]{2}{*}{$(10,1.1 \mathrm{kDa})$} & & Pig pancreatic juice $100 \% 60$ mins $^{89}$ & Rabbit 9 mins and 161 mins hal \\
\hline & & Human ileal $50 \% 35$ mins $^{9}$ & Human jejunal-30\% $3 \mathrm{hrs}^{9}$ \\
\hline 1 releasing & $0 \%$, immediate ${ }^{79}$ & Brushtail possum jejunal- $22 \min \mathrm{HL}^{10}$ & Rabbit-1.1\% $1 \mathrm{hr}^{90}$ \\
\hline Igs $(9 / 10,1.2-$ & & & Rat-24.8\% $5 \mathrm{hr}^{90}, 90 \mathrm{~min} \mathrm{HL}^{91}$ \\
\hline
\end{tabular}




\begin{tabular}{|c|c|c|c|}
\hline , 1.5kDa) & & $\begin{array}{l}\text { Rat duodenum } 0.4 \text { min } \mathrm{HL} \text {, jejunum } 0.4 \mathrm{~min} \\
\mathrm{HL} \text {, ileum } 36 \mathrm{~min} \mathrm{HL}^{6}\end{array}$ & \\
\hline sstinal peptide & $0 \%$ immediate $^{8}$ & & \\
\hline $3.4 \mathrm{kDa})$ & $0 \%, 1 \mathrm{hr}^{92}$ & $\begin{array}{l}\text { Rabbit- } 20 \mathrm{~min} \mathrm{HL}^{93} \\
\text { Rat-jejunal } 0 \% 5 \mathrm{~min}, 0.4 \mathrm{~min} \mathrm{HL}^{60}\end{array}$ & $\begin{array}{l}\text { Rabbit brush border enzymes- } 2 \\
\text { Rat jejunal- } 0 \% 25 \min ^{11}, 4.1-1 \text { । } \\
{ }^{94} \text {, Rat ileal } 5.59 \text { min half life }{ }^{11}\end{array}$ \\
\hline$\overline{34,4.1 \mathrm{kDa})}$ & & & Rat- $50 \% 3 \mathrm{hr}^{80}$ \\
\hline$(39,4.2 \mathrm{kDa})$ & & $\begin{array}{l}\text { Rat proximal-0.51-1.76 min } \mathrm{HL}^{68,95} \\
\text { Rat jejunal } 0.57 \mathrm{~min} \mathrm{HL}^{96}\end{array}$ & Rat proximal- $0.79{\mathrm{~min} \mathrm{HL}^{95}}^{95}$ \\
\hline$\overline{\mathrm{kDa})}$ & $10 \% 2 \mathrm{hr}^{81}$ & Pig-0\% $3 \mathrm{~min}^{82}$ & \\
\hline , $14.3 \mathrm{kDa})$ & $22.8 \%, 1 \mathrm{hr}^{83}$ & & \\
\hline $3 \mathrm{kDa})$ & $23.4 \%, 1 \mathrm{hr}^{83}$ & & \\
\hline$\overline{\mathrm{kDa})}$ & $17.7 \%, 1 \mathrm{hr}^{83}$ & & \\
\hline
\end{tabular}

